\title{
Substantive Justice in Provincial and Roman Legal Argument
}

\author{
Clifford Ando
}

\section{1 \\ Introduction}

There is more than one discourse of law in the Roman world, and justice plays several complicated roles in all of them. To the Roman world at large, the Romans promised to restore and sustain the rule of law. ${ }^{1}$ At a technical level, this generally meant supporting the on-going validity of local systems of law. More specifically, the Romans identified political units as sovereign within territories and allowed their law-making and law-applying institutions to operate throughout. ${ }^{2}$ But because the courts of Roman magistrates often functioned as courts of the second instance-in lay terms, they functioned as courts of appeal-Roman magistrates occasionally had to choose between local law and their own notions of justice or, one might say, between fulfilling, in any given decision, substantive or procedural justice. ${ }^{3}$ In short, if local rules of procedure had been carefully followed, would Roman magistrates honor the decisions of local courts, even if they did not like the outcome at a substantive level? Or would they invoke their own (Roman) notions of substantive justice, and overrule the local court? As it happens, in the discourse of law at Rome, there also

1 On the discourse of law and legal culture as features of empire and ideology, see A.Z. Bryen, 'Judging empire: courts and culture in Rome's eastern provinces', Law and History Review 30 (2012), 771-811; A. Bryen, 'Martyrdom, rhetoric and the politics of procedure', Classical Antiquity 33 (2014), 243-28o; see also C. Ando, Imperial Ideology and Provincial Loyalty in the Roman Empire (Berkeley 2000).

2 J. Fournier, Entre tutelle romaine et autonomie civique. L'administration judiciaire dans les provinces hellénophones de l'Empire romain (129 av. J.-C.-235 apr. J.-C.) (Paris 2010); C. Ando, 'Law and the landscape of empire', in S. Benoist, A. Daguey-Gagey, and C. Hoët-van Cauwenberghe (eds.), Figures d'empire, fragments de mémoire. Pouvoirs et identités dans le monde romain impérial (II s. av. n.è.-VI s. de n.è.) (Paris 2011), 25-47; G. Kantor, 'Law in Roman Phrygia: rules and jurisdictions', in P. Thonemann (ed.), Roman Phrygia. Culture and Society (Cambridge 2013), 143-167; C. Ando, 'Legal pluralism in practice', in P. du Plessis, C. Ando, and K. Tuori (eds.), The Oxford Handbook of Roman Law and Society (Oxford 2016), 283-293.

3 C. Ando, 'Pluralisme juridique et l' intégration de l' empire', in S. Benoist and G. de Kleijn (eds.), Integration in Rome and in the Roman World (Leiden 2013), 5-19. 
operated a tension between some understanding of the legal system as inherently just, on the one hand, and contingent concerns that excessive attention to rules or words might lead to a substantively unjust outcome, on the other. One object of the present paper is to bring these two conversations into comparative and historical relation.

Over the last generation, and with perhaps increasing stridency in recent years, Roman legal historians have sought to distinguish forms of inquiry that focus on law-in-books, which is to say, dogmatic legal history, from law-inaction. ${ }^{4}$ Another move distinguishes law at Rome from law in the provinces. These distinctions are of course related, evidence for legal practice under the Principate deriving largely from provincial evidence, just as the evidence for doctrine derives from jurists who worked at the capitol. The distinction between law-in-books and law-in action is, of course, a theoretical distinction that goes back a century in American legal scholarship. ${ }^{5}$ Virtually nothing of the debate about the utility or salience of this distinction in other contexts of inquiry has penetrated Roman legal scholarship: for those who invoke it, it has the status of a self-evident truth. It deserves more careful scrutiny than this.

In two bodies of recent work-both are in fact ongoing - I have tried to push back against any easy invocation of these distinctions, both more broadly against that between law-in-books and law-in-action, at least as the distinction is drawn by recent Roman legal historians, and more narrowly against that between law at Rome and law in the provinces. I did so first in respect of legal fictions and more recently in respect of analogical argumentation and rules of precedent. ${ }^{6}$ With regard to fictions, I showed that fictions were an essential tool in the writing of statute commencing from the very earliest surviving texts, figuring prominently in both the lex repetundarum and the lex agraria, especially in clauses that concern alien persons, land and actions. With regard to analogical argumentation, I have argued that it is visible to us in the records of pleadings in Roman courts first in the evidence of Roman Egypt. ${ }^{7}$ In both cases, therefore, the evidence from practice precedes the use and theorization of this material by the jurists. To be sure, the path that leads from procedu-

4 For a bibliography of recent surveys of legal historical research on Roman law see C. Ando, 'Roman law', in M. Dubber and C. Tomlins (eds.), The Oxford Handbook of Legal History (Oxford 2018), 663-679.

5 R. Pound, 'Law in books and law in action', American Law Review 44 (1910), 12-44.

6 C. Ando, 'Fact, fiction and social reality in Roman law', in M. del Mar and W. Twining (eds.), Legal Fictions in Theory and Practice (Boston 2015), 295-323.

7 C. Ando, 'Exemplum, analogy and precedent in Roman law', in M. Lowrie and S. Lüdemann (eds.), Between Exemplarity and Singularity: Literature, Philosophy, Law (New York 2015), 111122. 
ral and statutory fictions to the jurists is shorter and invites greater confidence than does that from provincial courts to Roman theory in the case of rules of precedent. But one need not insist on historical influence; the two bodies of evidence for analogical argumentation can be studied as merely mutually illuminating. The same, I think, can be said for the relationship of procedural and substantive justice in Roman and provincial legal argument.

When writing about Roman law, one regularly confronts the temptation to commence from Gaius or, better yet, from some obiter dictum of the Severan jurists, Papinian, Paul and Ulpian (or even Marcian). There is just a very great likelihood that one of these jurists will offer a formulation of economy and elegance in respect of the problem that one investigates. The problem, of course, is that economy and elegance of formulation are symptomatic not simply of the skill with language of some lone individual, but of hard-won clarity at the level of conceptualization - and, where institutionalized interpretive communities are concerned, like that of the jurists, conceptualization is a task of distributed agency. To begin with Ulpian is to begin when the brush has been cleared and the roads paved, and many problems have been resolved. ${ }^{8}$

As regards the topic of this paper, however, one of the more remarkable features of Roman debates regarding procedural and substantive justice is how mature the conversation appears as soon as its contours are visible to us. I am frequently skeptical that claims by jurists and other antiquarians of the high empire regarding the fourth, third and second centuries BCE should be trusted-most of the time, when they were not simply inventing, they had no empirical basis for their representations. So, for example, figures of the imperial period regularly attribute the motivation for the transition from legis actiones to ius honorarium to a concern for substantive justice, which is narrated as the process of overcoming the rigidity of actional formalism. ${ }^{9}$ That said, what we in fact see in some of the earliest texts that engage this and related issues, is instead a concern for justiciability. Consider, for example, the formulations offered by Cicero in his speech on behalf of Aulus Caecina, both in his own voice and in the words he attributes to Caecina's opponent, Sextus Aebutius:

8 A further problem is of course that in commencing with a normative account provided by the jurists, one is strongly urged to think and write dogmatically.

9 For the term 'actional formalism' see F. Schulz, History of Roman Legal Science (Oxford 1953 [1946]), 24-29. 
Quaero, sitne aliqua huius rei actio an nulla.

[Cicero, speaking in his own voice:] "I ask you, is there a legal process available in my case, or not?"

Cicero, Caec. 33; trans. after Hodge

Feci equidem quae dicis omnia; et ea sunt et turbulenta et temeraria et periculosa. Quid ergo est? Impune feci: nam quid agas mecum, ex iure civili et praetorio non habes.

[Cicero imagines the response of the legal opposition to his appeal for justice:] "I did indeed act in all respects as you describe, and such actions are riotous, reckless and dangerous. What of it? I acted with impunity, for in respect of your dealing with me, you have no recourse in either civil or praetorian law."

Cicero, Caec. 34; trans. after Hodge

Cicero's point, as will become clear, is that narrow punctiliousness in the interpretation of statutory language will issue in a non-fit between the facts of the case and the framework of the law, and the inability of the law to embrace such cases will produce a crisis of legal legitimacy. ${ }^{10}$ The problem of justice is not foregrounded, but it is latent.

Similar concerns about gaps between procedural rectitude and substantive justice emerge in nearly every reflection on the legal-historical change offered in Roman literature, and these provoke reflection by the jurists in at least three directions.

- First, the jurists ponder the nature and inevitability of historical social and linguistic change. On their representations, the content of statutes must first be accessed via the language and customs of their context of production, and yet language and customs change. Every aspect of the application of statute - the intelligibility of its language; the relationship of its terms to contemporary mores; the ability of a given statute to give normative description to the world it is called upon to regulate-is vulnerable to such processes of simple, inevitable historical change.

- Second, some of the problems that arise from such historical change can be redressed via the development of conventionally accepted modes of statu-

10 The testimony of this speech about the rise of praetorian law and jurisprudential reasoning is the subject of Bruce Frier's remarkable monograph, The Rise of the Roman Jurists. Studies in Cicero's Pro Caecina (Princeton 1985). 
tory interpretation. By this means, the fit between the language of statute and the world of contemporary language and social action can be repaired. That said, to acknowledge the need for interpretation is to acknowledge that a gap has opened up between the ipsissima verba of statute, narrowly construed, and contemporary modes of acting on statute that focus on its intent or meaning, what a Roman would call its vis. Acknowledgement of this gap involves a risk, namely, that it will summon forth advocates of fundamentalist or originalist literalism. How to constrain or foreclose the power of such claims of the past on the present is a major problem for many legal systems.

- Third, the jurists understand the legal system to have several means to close such gaps. In the Roman case, the means of choice in the classical period was, of course, praetorian law, which functioned, in Papinian's turn of phrase, "to aid, supplement or correct" statute law." It did so via a form of supersession, by simply establishing a new legal action, with different procedural requirements and often different outcomes. One might imagine that an effect of so proceeding was that statute law would lapse, via desuetude. But this is not how the jurists imagined the situation. Rather, the praetor simply ceased to grant actions narrowly on the basis of statute law, and instead granted actions grounded on his powers of jurisdiction. At this juncture there arose new problems of legal legitimacy with regard to recognition and respect among the sources of law at Rome. This is a problem about which I have written elsewhere, but I will write one word about it in this context, in just a moment. ${ }^{12}$

In what follows, I cite a few of the many reflections by Roman jurists on these issues by way of illustrating significant aspects and developments in their discourse on procedural and substantive justice.

Virtually every account of the replacement of the legis actiones by the formulary system is apposite to this argument. Here, for example, is the start and end of one such account, that of Gaius:

Actiones, quas in usu ueteres habuerunt, legis actiones appellabantur uel ideo, quod legibus proditae erant, quippe tunc edicta praetoris, quibus conplures actiones introductae sunt, nondum in usu habebantur, uel ideo, quia ipsarum legum uerbis accommodatae erant et ideo immutabiles proinde atque leges obseruabantur. unde eum, qui de uitibus suc-

11 Papinian, Definitiones bk. 2 frag. 46 Lenel = Dig.1.1.7.1 (trans. G. de St. Croix): Ius praetorium est, quod praetores introduxerunt adiuuandi vel supplendi vel corrigendi iuris civilis gratia propter utilitatem publicam. 
cisis ita egisset, ut in actione uites nominaret, responsum est rem perdidisse, quia debuisset arbores nominare, eo quod lex XII tabularum, ex qua de uitibus succisis actio conpeteret, generaliter de arboribus succisis loqueretur.

The actions of the practice of older times were called legis actiones, either because they were the creation of statutes (of course in those days the praetorian edicts, whereby a large number of actions have been introduced, were not yet in use), or because they were framed in the very words of statutes and were consequently treated as no less immutable than statutes. Hence it was held that a man who, when suing for the cutting down of his vines, having used the word "vines," had lost his claim, because he ought to have said "trees," seeing that the law of the Twelve Tables, on which his action for the cutting down of his vines lay, spoke of cutting down trees in general.

Gaius, Inst. 4.11; trans. after Zulueta

Sed istae omnes legis actiones paulatim in odium uenerunt. namque ex nimia subtilitate ueterum, qui tunc iura condiderunt, eo res perducta est, ut uel qui minimum errasset, litem perderet.

But all of these legis actiones gradually become unpopular. For because of the excessive punctiliousness of those who then established the law, matters were carried so far that someone who made the slighted mistake lost his case.

Gaius, Inst. 4.30; trans. after Zulueta

I limit myself to two observations about these passages. First, even here, in a passage that deplores the rigidity of the legis actiones, there is already visible a convention whereby a first-order term in statute, namely, trees, is treated as synecdochic of a second-order category or genus- "plants," I supposeof which the non-tree object at issue in any given dispute is also a particular or species. The legitimacy of this move is purchased via an historical sleight of hand that attributes this conception of language to the authors of the XII Tables, for it is the lex itself that is described as using the term "trees" in order to speak generaliter. ${ }^{13}$

13 For a sketch of Roman legal argument and language — and argument about language —in this domain, see C. Ando, Roman Social Imaginaries. Language and Thought in Contexts of 
My second observation concerns something that is not stated here, namely, that the production and especially the publication of the legis actiones were originally understood as democratic acts. For example, in his Handbook Pomponius interprets the history as follows:

Deinde ex his legibus eodem tempore fere actiones compositae sunt, quibus inter se homines disceptarent: quas actiones ne populus prout vellet institueret certas solemnesque esse voluerunt: et appellatur haec pars iuris legis actiones, id est legitimae actiones.

Then about the same time actions-at-law were composed out of these statutes [i.e., the laws of the Twelve Tables], on the basis of which people could resolve their disputes among themselves. To prevent the citizenry from initiating litigation any old how, the lawmakers' will was that the actions-at-law be in fixed and solemn terms; and this branch of law has the name legis actiones, that is, statutory actions-at-law.

Pomponius, Encheiridion frag. 178 Lenel = Dig. 1.2.2.6; trans. after G. de St. Croix

Both Gaius and Pomponius imagine legal history as determined by developments endogenous to legal institutions but above all as responding to exogenous pressures. Likewise, each thematizes issues of knowledge of law, legal legitimacy, formalism and justice. It is in keeping with their concern for legitimacy that Pomponius and, to a point, Gaius understand the legis actiones to have operated by giving procedural form to postulates of positive law enacted in the Twelve Tables. To my mind, this is obviously a fig leaf, genuflecting before some ideological principle of the simultaneous legitimacy of all unabrogated statutes. Nevertheless, the point remains that it had once been possible to understand the entire tradition of establishing and publicizing the legis actiones via statute- of using fixed and certain wording to solve a problem of knowledge of law - as democratic rather than pernicious. In this perspective, that the legis actiones eventually needed to be replaced was due not to some fault in their composition or even in the intent of those "who then established the law," but merely to the social change entailed by long passage of time.

Further reflection on these issues may be found in Gaius's contemporary Aulus Gellius, whose Attic Nights is our best contemporary source for the his-

Empire (Toronto 2015), 29-51; for a very different account, reaching different conclusions, see F. Schulz, Principles of Roman Law, trans. M. Wolff (Oxford 1936), 40-65. 
tory of Roman jurisprudence of the early imperial period. One of his talesperhaps the most famous in the tradition of literary reflection on the law ${ }^{14}$ derives from the Augustan jurist Antistius Labeo, namely, the anecdote about Lucius Veratius, who made sport of the law after the fashion of Sextus Aebutius as ventriloquized by Cicero. Sextus Aebutius, as we have seen, was imagined by Cicero to flaunt the lack of any remedy at law for Caecina, despite the avowed injustice of Aebutius' action. Veratius made sport of the law in a slightly different fashion:

Itaque cum eam legem quoque vester in libris, quos Ad Duodecim Tabulas conscripsit, non probaret: quidam, inquit, L. Veratius fuit egregie homo inprobus atque inmani vecordia. Is pro delectamento habebat, os hominis liberi manus suae palma verberare. Eum servus dequebatur ferens crumenam plenam assium; ut quemque depalmaverat, numerari statim secundum Duodecim Tabulas quinque et viginti asses iubebat. Propterea, inquit, praetores postea hanc abolescere et relinqui censuerunt iniuriisque aestumandis reciperatores se daturos edixerunt.

"And therefore your friend Labeo also, in the work that he wrote On the Twelve Tables [Huschke-Seckel-Kübler fr. 25], expressing his disapproval of that law, says: 'One Lucius Veratius was an exceedingly wicked man and of cruel brutality. He used to amuse himself by striking free men in the face with his open hand. A slave followed him with a purse full of asses; as often has he had buffeted anyone, he ordered twenty-five asses to be counted out at once, according to the provision in the Twelve Tables. Therefore,' he said, 'the praetors afterwards decided that this law was obsolete and invalid and declared that they would appoint arbiters to appraise damages.'”

Gellius 20.1.13; trans. after Rolfe

In the Lucius Veratius, the source of his power was not that he thought he had discovered a loophole in the language of statute, but that a rigid adherence to its terms exposed to mockery the diminution in value in real terms of the monetary penalty imposed by the law for simple assault.

The anecdote from Labeo is told by Favorinus in the course of a long conversation between the sophist and the jurist Sextus Caecilius, in which they

14 For a brilliant reading of this text see A.Z. Bryen, 'Crimes against the individual: violence and sexual crimes', in Du Plessis, Ando and Tuori, 2016, op. cit. (n. 2), 322-332. 
discuss how to understand legal change in relation to changes in language and mores. The arguments that Gellius attributes to Favorinus and Sextus Caecilius deserve attention, representing as they do a development on that employed by Labeo. That said, I am more interested in the other examples cited by the speakers in Gellius, for the framework of evaluation attributed to them also marks a development on Augustan jurisprudence:

Sed non levis existimator neque aspernabilis est populus Romanus, cui delicta quidem istaec vindicanda, poenae tamen huiuscemodi nimis durae esse visae sunt; passus enim est leges istas de tam inmodico supplicio situ atque senio emori. Sicut illud quoque non humaniter scriptum improbavit, quod, si homo in ius vocatus morbo aut aetate aeger ad ingrediendum invalidus est, arcera non sternitur, sed ipse aufertur et iumento imponitur atque ex domo sua ad praetorem in comitium nova funeris facie effertur.

Favorinus: "But the Roman people is a judge neither insignificant nor contemptible, and while they thought such crimes ought to be punished, they yet believed that punishments of that kind were too severe; for they have allowed the laws that prescribed such excessive penalties to die out from disuse and old age. Just so they considered it also to be not humanely prescribed that, if a man has been summoned to court, and being disabled through illness or years is too weak to walk, 'on a covered wagon he need not be spread'; but the man is carried out and placed on a beast of burden and conveyed from his home to the praetor in the comitium, as if he were a living corpse."

Gellius 20.1.10-11; trans. after Rolfe

"Quod si ita est, ut dico et ut ipse aequitatis habitus demonstrat, taliones illae tuae reciprocae argutiores profecto quam veriores fuerunt."

Caecilius: "But if this is as I say, and as the condition of fairness itself dictates, those mutual retaliations that you imagined were certainly more ingenious than real."

Gellius 20.1.35; trans. after Rolfe

It is a minor point, but Labeo is described as offering judgment on the character of Lucius Veratius: he was an egregie homo inprobus atque inmani vecordia. By contrast, although Favorinus and Caecilius disagree on the origin and location of the apparent severity of the law, they share a framework of substantive moral 
evaluation in light of which statute law, and rigid procedural acquiescence to it, should be assessed.

A final example derives from Hadrianic jurist Julian, and concerns testamentary succession. Wills are of course linguistic instruments, and they present to courts many of the same challenges of interpretation as were presented by the language of statute, and to them the jurists bring many of the same solutions. Hence, if we agree that a gap yawns between the voluntas of the testator (as between the vis of the law) and the effects that will issue from rigid adherence to the language of the will (as to statute), we require both conventional justifications for departing from that language, and conventional means for obtaining the result that we desire:

Si ita scriptum sit: "si filius mihi natus fuerit, ex besse heres esto: ex reliqua parte uxor mea heres esto. si vero filia mihi nata fuerit, ex triente heres esto: ex reliqua parte uxor heres esto," et filius et filia nati essent, dicendum est assem distribuendum esse in septem partes, ut ex his filius quattuor, uxor duas, filia unam partem habeat. Ita enim secundum voluntatem testantis filius altero tanto amplius habebit quam uxor, item uxor altero tanto amplius quam filia. licet enim suptili iuris regulae conveniebat ruptum fieri testamentum, attamen cum ex utroque nato testator voluerit uxorem aliquid habere, ideo ad huiusmodi sententiam humanitate suggerente decursum est, quod etiam Iuventio Celso apertissime placuit.

If a will was drawn up as follows, "If a son is born to me let him be heir in respect of two thirds, let my wife be heir in respect of the remaining part; but if a daughter is born to me, let her be heir to the extent of a third; let my wife be heir in respect of the remaining part," and both a son and a daughter were born, the decision must be that the whole inheritance should be divided into seven parts, so that the son gets four of them, the wife two, and the daughter one. For in this way, in accordance with the wishes of the testator, the son will have as much again as the wife and the wife as much more again as the daughter. For although it was agreed that by a nice rule of law the will was broken, yet, as the testator wished his wife to have something against both children, humanity suggests that a decision of this kind should be reached, which very clearly had the approval also of Juventius Celsus.

Julian, Digesta bk. 29 frag. 420 Lenel = Dig. 28.2.13.pr.; trans. W.M. Gordon

The contrast between subtilitas, procedural or interpretive punctiliousness, and humanitas (in this case), or benignitas or aequitas (in others), gets to the 
heart of my problem, and there may be just enough evidence to reveal a gradual change in the nature of the argument made by Romans about these problems. ${ }^{15}$ In the case of Roman theory about law at Rome, arguments over the relationship between procedural and substantive justice develop via reflection on social change. The earliest considerations of the issue concern narrowly justiciability and incommensurate punishments; they might therefore be said to focus on issues of legal legitimacy. But these debates give way by the Antonine period to a moral vocabulary that invokes standards of substantive justice, even among those, like Sextus Caecilius, who insists that neither the age of the decemviri nor his own was more just than the other. In his view, they are simply different. Furthermore, the arguments of the jurists in justification of their own practices of interpretation at the level of theory can be shown to follow upon the self-understanding of legal writers at Rome when they reflected on law-in-action.

Choice of Law, Legal Legitimacy and Substantive Justice in Provincial Contexts

I want now to trace a similar arc from the early first century в ве to the Antonine period, commencing with documents that arise from law-in-action before turning to theorizations on practice performed at Rome. I start with the Tabula Contrebiensis of $87 \mathrm{BCE} .{ }^{16}$ The inscription records the outcome of a legal procedure designed by the Roman governor Gaius Valerius Flaccus to resolve a dispute between two communities in Spain, the Sosinestani and Allavonenses, over the rights of one party to sell land and grant rights to dig a water channel to a third party. The procedure designed by Flaccus was based on the formulary procedure employed at Rome in private (civil-law) disputes: he wrote a formula, to wit, an authoritative description of the issues under dispute, and then appointed of a body of judges to hear the case and resolve exactly the questions framed in the formula. I focus on two aspects of the formula, namely, the meaning of the fiction in lines $6-8$, and also its relationship to the praeiudicium of ll. 1-5:

15 H. Hasmaninger, 'Subtilitas Iuris', in H.-P. Benöhr (ed.), Iuris Professio. Festgabe für Max Kaser zum 8o. Geburtstag (Vienna 1986), 59-72.

16 A text, translation and admirable exposition may be found in J.S. Richardson, 'The Tabula Contrebiensis: Roman law in Spain in the early first century BC', Journal of Roman Studies 73 (1983), 33-41. 
$1 \quad$ Senatus Contrebie[n]sis quei tum aderunt iudices sunto. sei par[ret ag]rum quem Sallvienses

ab Sosinestaneis emerunt rivi faciendi aquaive ducendae causa qua de re agitur Sosinestanos

iure suo Sallviensibus vendidisse inviteis Allavonensibus; tum sei ita parret eei iudices iudicent eum agrum qua de re agitur Sosinestanos Sallviensibus iure suo vendidisse sei non parr[e]t iudicent iure suo non vendidisse.

6 Eidem quei supra scriptei sunt iudices sunto. sei Sosinestana ceivitas esset tum qua Sallviensis

7 novissume publice depala[r] unt, qua de re agitur, sei [i]ntra eos palos Sallviensis rivom per agrum

8 publicum Sosinestanorum iure suo facere liceret aut sei per agrum preivatum Sosinestanorum

(1-5) Let those of the Senate of Contrebia who shall be present at the time be judges. If it appears, with regard to the land that the Salluienses purchased from the Sosinestani for the purpose of making a canal or channeling water, which matter is the subject of the dispute, that the Sosinestani were within their rights to sell it, although the Allavonenses were unwilling, then, if it so appears, let the judges judge with regard to the land which is the subject of the dispute that the Sosinestani were within their rights to sell it to the Salluienses; if it does not so appear, let them judge that they were not within their rights to have sold it.

(6-8) Let the same persons who are written above be judges. If it is supposed that $\langle$ there is, in fact, a Sosinestan civitas〉, then, in the place where the Salluienses recently and officially put in stakes, which matter is the subject of this action, if it would be permissible for the Salluienses within their rights to lead a canal within those stakes through the public land of the Sosinestani ...

The overall procedure is, of course, Roman. Many understand it on analogy with the formulary process, insofar as joinder of issue was conducted before the magistrate, while the trial itself was conducted before iudices appointed by him, and that is held to be a remarkable and noteworthy thing. Nor do I dispute this, though there is in fact every reason to believe that many trials before provincial governors were conducted in precisely this way. This text is remark- 
able because it is early, and because it concerns a matter of public law. All that to one side, I focus on the fiction because, on my reading, it addresses the questions of what standards of justice and rules of evidence are to be applied by the judges in this case. The answer supplied by the fiction is that they are those of the Sosinestan civitas, whose status as an autonomous polity with its own lawmaking institutions is contingently resolved by the fiction. ${ }^{17}$

On this reading, the fiction might be understood as a violent intervention in the case, resolving as it does precisely the issue apparently disputed by the Allavonenses, who are revealed by the praeiudicium to have denied that the Sosinestani were within their rights in selling the land in the first place (line 3). But of course the fiction of the autonomy of the Sosinestani only becomes operative once the judges have ruled on the praeiudicium: in the cascading sequence of conditionals that make up the formula, the (indigenous) judges must first settle the question of whether the Sosinestani were within their rights to sell. On this reading, the fiction in the intentio performs two tasks: it glances back to the question posed in the praeiudicium and so acknowledges the protest of the Allavonenses; it then allows the case to proceed only under the condition of a ruling in the affirmative on the question that they have deemed paramount. The fiction might therefore appear tautological or simply pleonastic. To my mind, it is both clever and correct. This reading has the benefits of treating the Latin of the fictio as saying what it most obviously does and of bringing the two parts of the formula into close convergence with one another.

Substantively, then, the fiction is intended to resolve the question of choice of law. That the Romans had long reflected on principles of choice of law in situations of international private law is clear from the treaties that Rome struck with Carthage, and a mature language for discussing and resolving such issues is eminently on display in the Senatus consultum de Asclepiade of the year $78 .{ }^{18}$ In that text, individuals who are denominated friends of the Roman people are given the right to forum-shop, namely, to take their dispute either to a court in the city of their citizenship, or a nearby city, or to have it heard by the Roman governor, according to their view of which jurisdiction's positive law was most favorable to them. My point is simply that the Tabula Contrebiensis exhibits in a particularly clear fashion a sophisticated capacity to distinguish

17 For specialists, I acknowledge that I understand the nature of the fiction differently than do Birks, Rodger and Richardson: P. Birks, A. Rodger and J.S. Richardson, 'Further aspects of the Tabula Contrebiensis', Journal of Roman Studies 74 (1984), 45-73.

18 A. Raggi, 'Senatus consultum de Asclepiade Clazomenio sociisque', Zeitschrift für Papyrologie und Epigraphik 135 (2001), 73-116. 
the technicalities of procedure from choice of law, even when, as in this case, the standards are those of positive law rather than substantive justice.

The practice attested by these texts of the late republic is given normative description in Antonine texts of the second century in two significant respects. The first is the definition of ius civile provided at the opening of Gaius' Institutes:

Omnes populi qui legibus et moribus reguntur partim suo proprio, partim communi omnium hominum iure utuntur: nam quod quisque populus ipse sibi ius constituit, id ipsius proprium est vocaturque ius civile, quasi ius proprium civitatis; quod vero naturalis ratio inter omnes homines constituit, id apud omnes populos peraeque custoditur vocaturque ius gentium, quasi quo iure omnes gentes utuntur.

All peoples who are governed by statutes and customs observe partly their own peculiar law and partly the common law of all human beings. The law that each people establishes for itself is peculiar to it, and is called ius civile, being, as it were, the special law of that civitas, that community of citizens, while the law that natural reason establishes among all human beings is followed by all peoples alike, and is called ius gentium, being, as it were, the law observed by all peoples.

Gaius, Inst 1.1

The heart of Gaius's claim is contained in the distributive and reflexive pronouns quisque and sibi: ius civile denotes those bodies of law that each political community makes for itself. No evaluative framework-no transcendent standard of substantive justice-is offered to adjudge between these codes of law. The operative assumption would seem to be that local social orders are best secured by adherence to locally-generated norms, and, as a related matter, the legitimacy of those codes of law is underwritten by a commitment to democratic authorization.

With these remarks in mind, let us turn to a similar Roman account, that provided by the jurist Julian of the sources of norms to which Roman governors should have recourse when functioning as a court of the first instance in provincial contexts. If the relevant statute is available in written form, that has preference by default. Hence, Julian specifies a cascading series of norms only when written law fails:

De quibus causis scriptis legibus non utimur, id custodiri oportet, quod moribus et consuetudine inductum est: et si qua in re hoc deficeret, tunc 
quod proximum et consequens ei est: si nec id quidem appareat, tunc ius, quo urbs Roma utitur, servari oportet.

What ought to be held to in those cases where we have no applicable written law is the practice established by customs and usage. And if this is in some way deficient, we should hold to what is closest to and entailed by such practice. If even this is obscure, then we ought to apply the law which the city of Rome uses.

Julian, Digesta bk. 84 fr. 819 Lenel = Dig. 1.3.32.pr.; trans. G. de St. Croix

Here it is essential to attend to what is not specified as relevant to adjudication, and that is justice: iustitia is not cited, nor is reference made to humanitas, nor should one deliberate benigne, nor proceed ex bono et aequo. As with Gaius's resolute parallelism of codes of citizens' law, which derive their legitimacy solely from their authorization via local law-making institutions, so for Julian, the norms to be applied by Roman courts are those of positive or customary law, or such principles of conduct as can be abstracted from patterns in conventional practice. No normative framework, whether of morality or transcendent justice or what have you, is cited with which one might evaluate those norms prior to their application to the case at hand.

Nevertheless, already in the age of Julian, a discourse and practice of evaluating specific local practices, and in particular of judging specific cases, by standards of substantive justice was starting to emerge. ${ }^{19}$ One of the most notable early cases is known via its citation in the petition of Dionysia. ${ }^{20}$ Dionysia filed a petition with the prefect of Egypt sometime after 27 June 186, seeking resolution to a dispute with her father, in part of which her father insisted upon his right, grounded in local law, to order her daughter to divorce her husband against her will. The text has been the subject of some superb scholarship, but some of its details nevertheless repay further attention. In particular, Dionysia's petition is notable not simply for her own commitment to textualism, but

19 For an exemplary study of a related problematic, with different emphases than my own, see C. Kreuzsaler and J. Urbanik, 'Humanity and inhumanity of law: the case of Dionysia', Journal of Juristic Papyrology 38 (2008), 119-155:142-153. They focus on appeals to humanity and especially inhumanity as moral values that enable revision or abrogation of law, but their exploitation of both Roman and provincial evidence is wholly consonant with the form and thrust of my own text.

20 On the petition of Dionysia see C. Kreuzsaler, 'Dionysia vs. Chairemon: ein Rechtstreit aus dem römischen Ägypten', in U. Falk, M. Luminati, and M. Schmoeckelin (eds.), Fälle aus der Rechtgeschichte (Munich 2008), 1-13; and especially Kreuzsaler and Urbanik 2008, op. cit. (n. 19). 
that of nearly every actor in the system to whom she alludes. So, for example, Dionysia cites an extract from a hearing before the prefect Titianus in the twelfth year of Hadrian concerning divorce, in which the judgment of Titianus is that the preference of the woman should determine where she lives. Dionysia next cites a hearing before Paconius Felix, epistrategus of the Sebennyte nome, from the eighteenth year of Hadrian, where an interpretation is offered, or, you might say, a rationale is ascribed to Titianus in so ruling: he had not wanted to

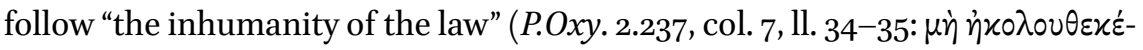

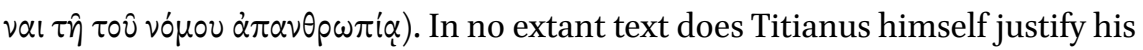
judgment in these terms: this is a matter of what we might call rational reconstruction on the part of another official, who needs to use an earlier judgment. He might have done so via narrowly analogical argumentation. He chooses instead to abstract from the earlier judgment-which is to say, he ascribes to the holder of jurisdiction in that earlier situation - a concern for transcendent principles of substantive justice. That is a wholly different basis for establishing precedental value.

We see similar justifications emerge even in what we might call public law contexts, or, at least, in contexts of policy regarding public law, in just this period. Its condition makes it impossible to know the context in which it intervenes or its exact date-it has been assigned by various critics anywhere from the reign of Hadrian to the reign of Antoninus Pius; its condition likewise precludes a continous translation. Nevertheless, the inscription from Nicomedia published as TAM 4.1.3 clearly imagines conditions under which the local boulê acts unjustly, $\mu \grave{\eta} \delta$ ox $\alpha^{\prime} \omega \varsigma$ (l. 5):

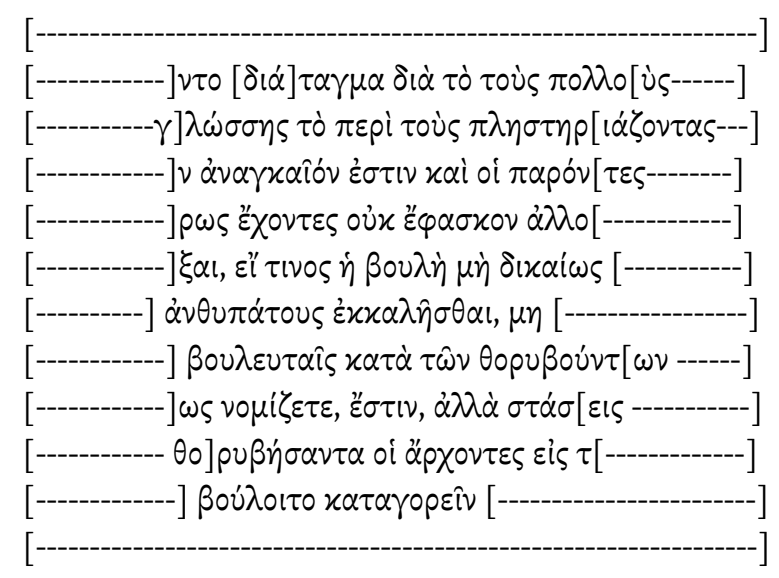

What is more, it is apparently precisely the fact of an unjust decision by the local council that is imagined to motivate an appeal to Rome (l. 6). That is to 
say, in line 5 , a conditional commences, "If the city council unjustly ...," while in line 6 an appeal is made to the proconsular governor. Select words in the rest of the text suggest varied forms of local political disturbance or even upheaval, but the details elude us. Nevertheless, either we must imagine that Rome concerned itself with the possibility that the local decision violated local norms, or it here invokes a transcendent-a substantive - notion of justice, as a framework of evaluation for the operation of local institutions of government.

\section{Conclusion: Procedural Justice, Roman-Style}

I have surveyed legal argument at Rome and in the provinces from the first century BCE to the Antonine period, and I have suggested that each displays a limited form of chronological development, toward the rise to salience of appeals to substantive justice over against procedural correctness or positive or immanent law, with their separate commitments to democratic notions of legal legitimacy. But no such history can be unitary, particularly as the relationship between procedure and positive law in the Roman formulary process was so complex. ${ }^{21}$ What is more, procedural justice is not defined by a concern merely for procedural correctness, but for transparency, fairness and so forth. I would therefore like to close by reminding us that the Romans also sought to actualize standards of justice through the imposition of standards of procedure, most notably in criminal law. The most famous example derives from the governorship of Antoninus Pius in the province of Asia, as it is cited by Marcian and apparently elaborated upon by himself and later emperors:

Sed et caput mandatorum exstat, quod divus Pius, cum provinciae Asiae praeerat, sub edicto proposuit, ut irenarchae, cum adprehenderint latrones, interrogent eos de sociis et receptatoribus et interrogationes litteris inclusas atque obsignatas ad cognitionem magistratus mittant. igitur qui cum elogio mittuntur, ex integro audiendi sunt, etsi per litteras missi fuerint vel etiam per irenarchas perducti. sic et divus Pius et alii principes rescripserunt, ut etiam de his, qui requirendi adnotati sunt, non quasi pro damnatis, sed quasi re integra quaeratur, si quis erit qui eum arguat. et

21 See, e.g., the hugely insightful observation by Birks, Rodger and Richardson 1984, op. cit. (n. 17), 6o: 'Nowadays we easily think of pleading and procedure as matters separable from the substance of the law. But under the formulary system, the texts of the formulae were the foundations of substantive law, and innovation in their wording was the principal means by which that substantive law was changed.' 
ideo cum quis anakrisin faceret, iuberi oportet venire irenarchen et quod scripserit, exsequi: et si diligenter ac fideliter hoc fecerit, collaudandum eum: si parum prudenter non exquisitis argumentis, simpliciter denotare irenarchen minus rettulisse: sed si quid maligne interrogasse aut non dicta rettulisse pro dictis eum compererit, ut vindicet in exemplum, ne quid et aliud postea tale facere moliatur.

There is indeed extant a chapter of the rules that the deified Pius issued under his edict when he was governor of the province of Asia: that irenarchs, when they had arrested robbers, should question them about their associates and those who harbored them, include their interrogatories in letters, seal them, and send them for the attention of the magistrate. Therefore, those who are sent [to court] with a report [of their interrogation] must be given a hearing from the beginning although they were sent with documentary evidence or even brought in by the irenarch. The deified Pius and other emperors have written in rescripts to this effect: that even in the case of those who are listed as wanted, if anyone appears to prosecute one [of these], they should not be treated as condemned but as though a charge were being laid afresh. Accordingly, when someone carries out an examination, the irenarch should be ordered to attend and to go through what he wrote. If he does this painstakingly and faithfully, he should be commended; if [he does it] with insufficient skill and not with thorough reasoning, [the judge] simply notes that the irenarch has rendered an inadequate report; but if [the judge] finds that his interrogation was in any way malicious, or that he reported things that were not said as if they had been said, he should impose an exemplary punishment, to prevent anyone else trying anything of the kind afterward.

Marcian, De iudiciis publicis bk. 2 frag. 204 Lenel = Dig. 48.3.6.1; trans. O. Robinson

On the representation provided by Marcian, the edict of Pius imposed procedural standards on non-Roman communities, at least in those cases where a Roman court would serve as court of the first instance. The purpose of those standards is then clarified by the commentary provided by Pius as emperor (along with unnamed others), whose attention in this text focuses on the moral character of the irenarch as it is actualized and then revealed through procedure. It is the irenarch who is the object of the magistrate's anakrisis; it is the irenarch who might act diligenter ac fideliter and so earn praise; or parum prudenter non exquisitis argumentis; or even maligne, reporting things not as they were said, and so earn punishment in exemplum. 
The case of criminal law is of course special: in criminal jurisdiction, it is common to say that power was taken out of the hands of local officials because Rome sought to monopolize the right to authorize the use of force in violent punishment. But it would perhaps also be accurate to say that in criminal law, local officials were instrumentalized in order to extend the reach of the Roman state. That being so, the non-hierarchical modes of recognition practiced by Rome in respect of systems of civil law could not be sustained in criminal law.

That said, discourses on justice in civil and criminal law, both Roman and provincial, have similar trajectories in the high Roman empire, and even similar chronologies. This must surely result in part from cognitive pressures that inhere in metropolitan epistemes within pluralist empires. The full unfolding of that history is, of course, ongoing. 